\title{
Zooplankton vertical distribution and migration off Central Peru in relation to the oxygen minimum layer
}

\author{
M. I. Criales-Hernández $\cdot$ R. Schwamborn • M. Graco • \\ P. Ayón · H.-J. Hirche • M. Wolff
}

Received: 31 May 2007 / Revised: 10 September 2007 / Accepted: 1 October 2007 / Published online: 23 November 2007

(C) Springer-Verlag and AWI 2007

\begin{abstract}
Vertical distribution and diel vertical migration of a zooplankton community were studied at two stations off Central Peru in April 2006. Zooplankton was collected at five depth strata by vertical hauls with Hydo-Bios multinet (300- $\mu \mathrm{m}$ mesh, $0.25-\mathrm{m}^{2}$ mouth size). The zooplankton community was distributed in relation to a strong, shallow oxycline $\left(1 \mathrm{ml}^{-1}\right.$ oxygen isopleth generally above $\left.36 \mathrm{~m}\right)$. The highest total abundance was always in the upper, welloxygenated layer. The most important species were: Acartia tonsa (72.86\%), Centropages brachiatus (7.5\%), and Paracalanus parvus (3.1\%); Acartia tonsa was the dominant species at all times. Larvae of the polychaete Magelona sp. (7.5\%) and larvae of the brachiopod Discinisca lamellosa (3.5\%) were numerically dominant in April and small copepods e.g. Oncaea venusta $(3.88 \%)$ were numerically dominant during August. Five distinct patterns of vertical distribution and migration in relation to the oxygen
\end{abstract}

Communicated by S. Thatje.

Communicated by: Sven Thatje. Special Issue: Climate variability and El Niño Southern Oscillation: implications for natural coastal resources and management. S. Thatje (ed.)

M. I. Criales-Hernández $(\bowtie) \cdot$ M. Graco · P. Ayón

Instituto del Mar del Perú, Lima, Peru

e-mail: micriales@imarpe.gob.pe

R. Schwamborn · H.-J. Hirche

Alfred Wegener Institute for Polar and Marine Research,

Bremerhaven, Germany

R. Schwamborn

Zoology Department,

Universidade Federal de Pernambuco, Recife, Brazil

M. Wolff

Center for Tropical Marine Ecology, Bremen, Germany minimum layer were distinguished in this study: (1) Ontogenetic vertical migration through the oxycline (Acartia tonsa adults, nauplii, and copepodids), (2) permanent limitation to layers above the oxycline (e.g. Oikopleura sp., most invertebrate larvae), (3) distribution mostly below the oxycline with occasional migration into the layers just above the oxycline (Eucalanus inermis), (4) Diel Vertical Migration (Centropages brachiatus), and (5) reverse Diel Vertical Migration (larvae of the polychaete Magelona sp.).

Keywords Vertical distribution - Zooplankton community $\cdot$ Central Peruvian Coast

\section{Introduction}

The waters off Central Peru are productive regions that support economically important fisheries (Carrasco and Lozano 1989; Chavez et al. 2003; Alheit and Niquen 2004). Another characteristic of this region is a well-developed oxygen minimum layer (Wyrtki 1967; Judkins 1980; Mackas et al. 1981), which occurs nearly continuously in most of the Humboldt Current System (Zuta and Guillen 1970; Heinrich 1973; Calienes and Guillen 1981; Pizarro et al. 2002).

Previous works in the Humboldt Current System have suggested that some zooplankton populations display specific patterns of vertical stratification related to changes in environmental conditions in these regions. Judkins (1980) found a discrete vertical distribution of zooplankton over the shelf and slope off Central Peru. Oxygen appeared to be the most important environmental factor determining zooplankton distribution. Again Smith et al. (1981a) and Mackas et al. (1981), found that the thermocline and oxycline appeared to divide the upper $30 \mathrm{~m}$ into fairly distinct 
copepod and non-copepod faunal zones. Antezana (2002) described the vertical migration patterns of Euphasia mucronata. Larvae, juveniles and adults of this species were found in the upper $50 \mathrm{~m}$ layers during night hours, migrating to deeper layers near sunrise. The majority of copepods are found in the upper $40 \mathrm{~m}$ both during day and night, probably due to anoxic water below (Boyd et al. 1981; Sameoto 1981). This behaviour is similar to other species in the eastern South Pacific where adult populations are mostly above $50 \mathrm{~m}$ in both oceanic (Longhurst 1967; Flint 1975; Saltzman and Wishner 1997) and coastal waters (Flint et al. 1991). Recently, detailed studies on the vertical distribution of selected copepod species have been conducted in the Humboldt Current System off northern Chile, with emphasis on diel vertical migration performed by the deep-dwelling Eucalanus inermis (Hidalgo et al. 2005; Escribano 2006).

The shelf waters off Callao (Central Peru) were chosen for this study because of their intensive upwelling. Furthermore, an extremely shallow oxygen minimum layer is generally found during upwelling conditions, potentially restricting the available vertical amplitude of migrant species. In spite of its fundamental importance in fisheries and biogeochemical processes, new data on vertical distribution of zooplankton from this area are still lacking. Previous studies in this area were conducted several decades ago (Smith et al. 1981b; Boyd et al. 1981; Semenova et al. 1982). Smith et al. (1981b) studied the vertical migrations of three groups of copepods (Oncaeidae, Oithonidae, small Calanoida) with a $5-\mathrm{m}$ resolution at $9^{\circ} \mathrm{S}$. The oxygen minimum layer established a distinct lower boundary for the distribution of many organisms. During daytime, all three groups accumulated above the oxycline, while at night, small calanoids were always more abundant in the upper layers than Oncaeidae. Restriction to the upper $20 \mathrm{~m}$ maintains zooplankton within currents, which may vary to a great extent in this complex upwelling system (Brink et al. 1980) and have strong influence in the onshore-offshore dimension (Smith et al. 1981b). Boyd et al. (1981) observed that E. inermis, Calanus sp. and Centropages brachiatus, show different patterns of diel vertical migration inshore and offshore at $9^{\circ} \mathrm{S}$. Semenova et al. (1982), described the vertical and horizontal distribution patterns of 37 species at 26 stations along the transect between $7^{\circ}$ and $15^{\circ} \mathrm{S}$. Only two species have been found to be able to penetrate and even stay in the oxygen minimum layer.

A better knowledge about the vertical movement and distribution of the whole population is required to evaluate their role in the active vertical transport of energy and matter in this intense upwelling region. Although there is a plethora of studies describing vertical distribution and migration in marine zooplankton (see recent reviews in Hays 2003; Pearre 2003), only a few studies were conducted explicitly considering and testing the fluctuations in cline depths (Haury et al. 1983; Trevorrow 1998; McManus et al. 2005), or testing the effect of specific abiotic variables on migrating organisms (Cohen and Forward 2002; Renz and Hirche 2006). Previous studies on vertical distribution and migration of zooplankton conducted off Peru have not yet explicitly tested the hypotheses related to specific abiotic variables and fluctuations in cline depths.

The present study aims at characterizing and analyzing the vertical distribution and migration patterns of zooplankton in the Cold Coastal Waters (CCW), which are typical of the highly productive upwelling ecosystems of the Humboldt Current System. The aims of the present study are to characterize and analyse the vertical distribution and migration patterns of zooplankton, and particularly to analyse the effect of cline depths, specifically the depth of the oxygen minimum layer, on zooplankton in the Callao shelf waters.

\section{Materials and methods}

\section{Sampling}

Zooplankton vertical distribution and migration were studied at a nearshore (station 2) and an offshore station (station 5) off Central Peru $\left(12^{\circ} 02.03 \mathrm{~S} 77^{\circ} 17.32 \mathrm{~W}\right.$ and $12^{\circ} 02.4 \mathrm{~S}$ $77^{\circ} 39.1 \mathrm{~W}$, respectively). It is an open shore area (Fig. 1), wherein a widening of the shelf is observed (Carrasco and Lozano 1989). The stations are located in an upwelling zone with elevated levels of primary production during most of the year (Zuta and Guillen 1970). Station 2 is located on the nearshore shelf at 93-m depth, while station 5 is located further offshore above the shelfbreak, with a column depth of $176 \mathrm{~m}$. In April and August 2006, zooplankton samples were collected over 24-h periods at both stations. Vertically stratified tows were taken with a multinet (Midi model, $50 \times 50 \mathrm{~cm}$ mouth size, Hydro-Bios,

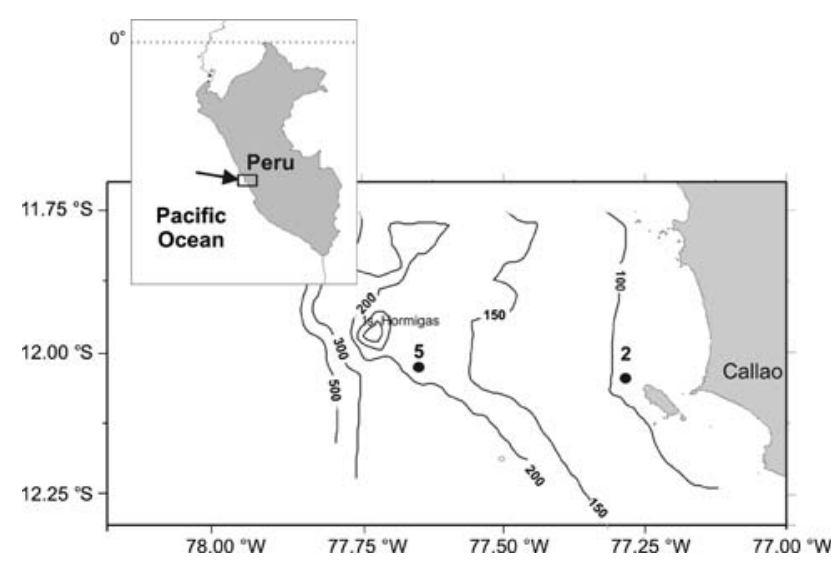

Fig. 1 Map of the study area off Central Peru showing both sampling stations 
Kiel) equipped with five $300-\mu \mathrm{m}$-mesh nets approximately every $3 \mathrm{~h}$. Each of the Five nets was equipped with a calibrated Hydro-Bios flowmeter, to allow for individual estimates of filtered volume for each sample. Depth strata sampled by each net were: (1) maximum depth of $50 \mathrm{~m}$, (2) 50-30 m, (3) 30-20 m, (4) 20-10 m, and (5) $10 \mathrm{~m}$ to surface. This sampling strategy was chosen to ensure a consistent sampling of the three main strata (oxygen minimum layer, oxycline, and upper layer) of the water column. The first net was deployed for sampling the deepest, hypoxic stratum inside the oxygen minimum layer; the last uppermost net was always sampling the well-oxygenated upper layer, while the intermediate nets were intended for sampling the oxycline and one of both layers, depending on the oxycline depth. Maximum depth sampled with the first net varied from 100 to $75 \mathrm{~m}$, depending on local conditions. Samples were preserved in $4 \%$ formaldehyde buffered with borax in seawater solution.

Immediately after each haul, environmental data were obtained with a CTD (Seabird model SBE 19) equipped with sensors for depth, temperature, salinity, chlorophyll $a$ fluorescence (Haardt, Kiel), and an optical oxygen sensor (Aanderaa model 3830). Additionally, water samples for chlorophyll $a$ measurements were obtained at discrete depths $(0,10,25,50,75,94 \mathrm{~m}$ at station 2 and $100 \mathrm{~m}$ at station 5) using a rosette system equipped with 5-1 Niskin bottles. For each depth, samples of $200 \mathrm{ml}$ were immediately filtered on $\mathrm{GF} / \mathrm{F}$ filters and refrigerated until the analysis. Later, the filters were extracted in $90 \%$ acetone and measured in the laboratory (Holm-Hansen et al. 1965) with a previously calibrated desk fluorometer (Turner Designs 10-AU).

Generally, whole zooplankton samples were analysed. When the density exceeded 200 individuals per species, the samples were split using the Hustman Marine Laboratory beaker technique (Van Guelpen Louis et al. 1982). All copepods were identified to the lowest taxonomic level possible and counted under a stereomicroscope. Invertebrate larvae were identified with the available literature (Gurney 1942; Banse and Hobson 1974; Albornoz and Wehrtmann 1997; Pohle et al. 1999; Thuesen and Fernandez 1999).

Data analysis

Zooplankton abundance was calculated in terms of density (ind. $\mathrm{m}^{-3}$ ) based on flowmeter readings. The most abundant and frequent taxa were chosen for analyses of vertical distribution and correlation to abiotic variables. To assess the vertical distribution center for each taxon and stage at a given time, the weighted mean depth was calculated for each multinet haul (Roe et al. 1984; Pillar et al. 1989). To characterize the vertical distribution in relation to the oxygen minimum layer, the percentage of the abundance in the top oxygenated layer in relation to the total abundance per haul $\left(P_{\text {oxy }}\right)$ was calculated for each taxonomic group. The top oxygenated layer was defined as the Multinet strata sampled above the $1 \mathrm{ml} \mathrm{l}^{-1}$ oxygen isopleth. Weighted mean depth and $P_{\text {oxy }}$ were only calculated for taxa and stages that displayed total vertically integrated densities in a given multinet haul of at least 0.3 ind. $\mathrm{m}^{-2}$.

By comparing changes in weighted mean depth and $P_{\text {oxy }}$, we were able to distinguish and ascertain which organisms potentially exhibit migration in relation to daytime and oxycline dynamics. Specifically, we tested our data for diel vertical migration (significant differences in WMD between day and night), and diel migration through the oxycline (significant differences in $P_{\text {oxy }}$ between day and night), and migration following the oscillations of the oxycline (significant correlation of weighted mean depth and oxycline depths). To verify whether diel vertical migration occurred, weighted mean depth and $P_{\text {oxy }}$ were tested for differences between day and night for the most abundant taxa using non-parametric Mann-Whitney tests. To check whether diel vertical migration of organisms were due to daily fluctuations of cline depths, thermo- and oxycline depths (depths of the $15^{\circ} \mathrm{C}$ isotherm and $1 \mathrm{ml} \mathrm{l}^{-1}$ oxygen isopleth) were also tested for differences between day and night using non-parametric Mann-Whitney tests. For taxa, where different life history stages occurred (e.g. copepodids and adults of copepods), weighted mean depth and $P_{\text {oxy }}$ were compared between stages to test for ontogenetic vertical migration with nonparametric Wilcoxon tests for paired samples. Spearman rank correlation analysis was used to test for significant correlations between environmental variables (depth, temperature, salinity, oxygen, and laboratory-derived chlorophyll a) and abundance by stratum and time, for the main taxa and stages, using one average value per sample and depth stratum ( $n=$ up to 120). Spearman correlations were also calculated between weighted mean depth, $P_{\text {oxy }}$, and the depths of the $15^{\circ} \mathrm{C}$ isotherm and $1 \mathrm{ml}^{-1}$ oxygen isopleth, for the main taxa and stages, using one value per multinet haul ( $n=$ up to 24). Statistical tests were performed using Statistica 6.1.

\section{Results}

Hydrographical conditions

During April, the water column at both stations showed the presence of $\mathrm{CCW}$, with an extremely shallow and oscillating thermocline $\left(15^{\circ} \mathrm{C}\right.$ isotherm) located at $10-20 \mathrm{~m}$ depth at the nearshore station 2 (Figs. 2, 3). The thermocline was deeper offshore, being $20-40 \mathrm{~m}$ at station 5 . Surface waters displayed temperatures between 16 and $17^{\circ} \mathrm{C}$ in April. Deeper waters $(\mathrm{ca} .75 \mathrm{~m})$ showed temperatures around $14^{\circ} \mathrm{C}$. The vertical distribution and variability of the thermocline was coincident with the variability of the sharp, shallow oxycline 
Fig. 2 Examples of vertical CTD profiles of salinity, temperature, oxygen concentration, and chlorophyll $a$ fluorescence obtained during the predominance of cold coastal waters (Station 2 in April, a above) and subtropical surface waters (Station 2 in August, $\mathbf{b}$ below)

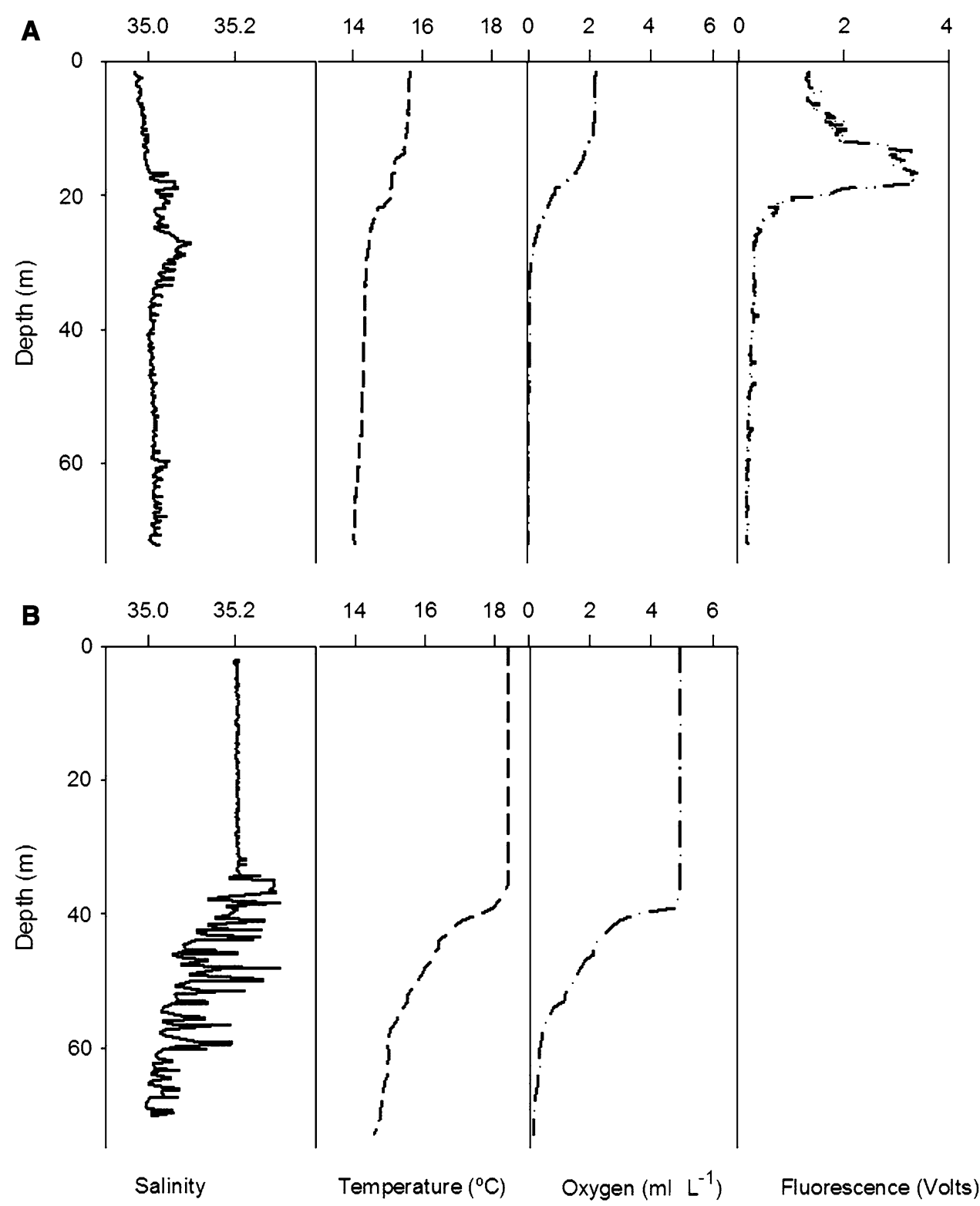

column with a significant deepening of the $15^{\circ} \mathrm{C}$ isotherm down to more than $60 \mathrm{~m}$ (Figs. 2, 3). A much more oxygenated water column characterized this period with a deeper oxycline, particularly at station 5 , where $Z_{\text {oxy }}$ was mostly below $50 \mathrm{~m}$ (Fig. 3). Salinity was higher than in April, with values between 35.1 and 35.3, indicating the presence of subtropical surface waters (SSW) on the shelf. The thermocline and oxycline showed a strong vertical variability over $24 \mathrm{~h}$, particularly at station 2 (Fig. 3).

Thermo- and oxycline depths $\left(Z_{\text {oxy }}\right.$ and $\left.Z_{\text {therm }}\right)$ displayed considerable oscillations within $24 \mathrm{~h}$, especially at station 2 in August and at station 5 in April, when the amplitude of oscillations in $Z_{\text {oxy }}$ and $Z_{\text {therm }}$ were approximately $20 \mathrm{~m}$ (Fig. 3). Wavelength of these oscillations was approximately $12 \mathrm{~h}$ during these two 24-h series, with two peaks per $24 \mathrm{~h}$. At station 5 in April, thermo- and oxyclines 

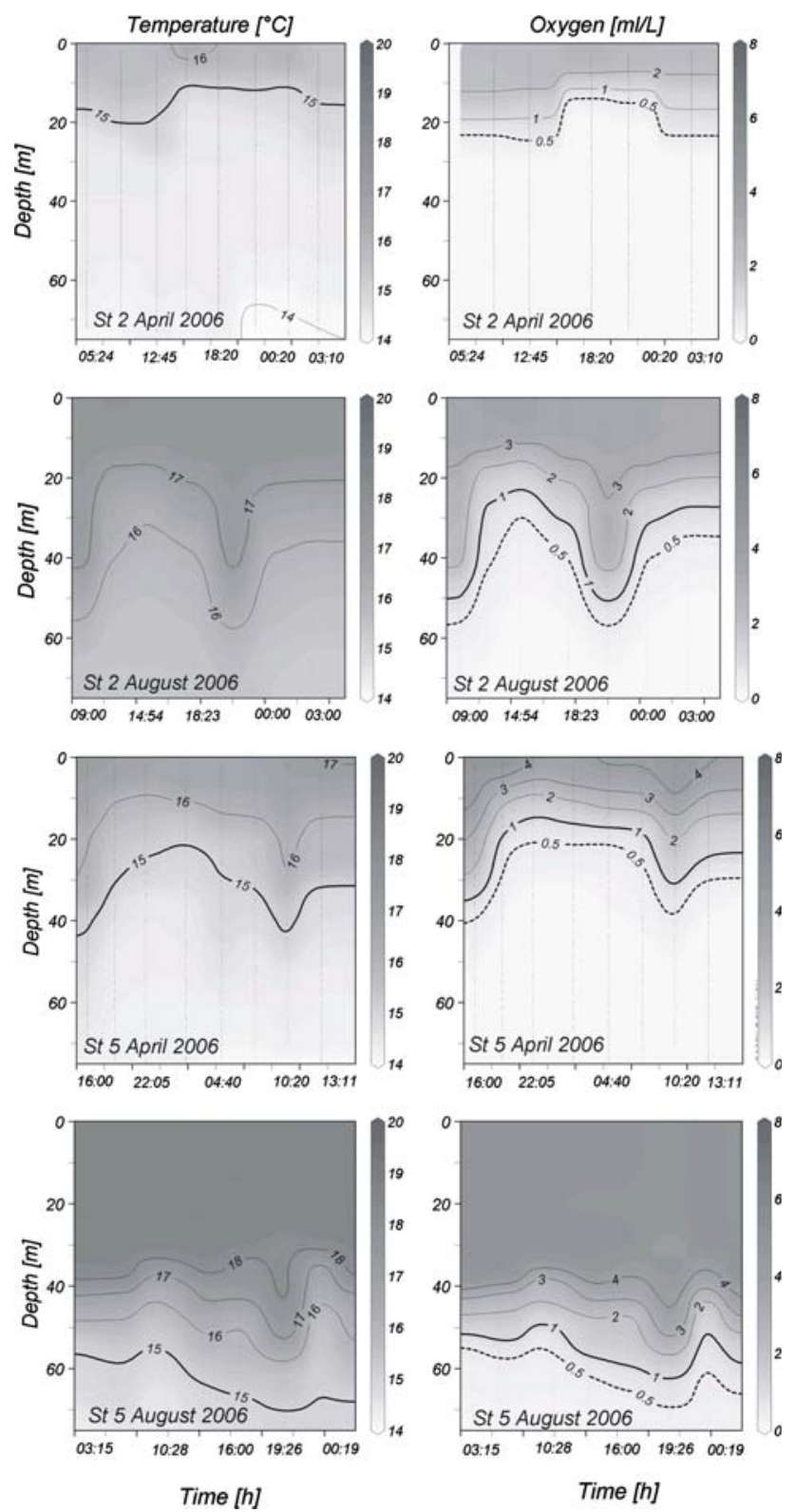

Fig. 3 24-h variation of the vertical distribution of temperature and oxygen concentration at stations 2 and 5 off Central Peru in April and August 2006

displayed a major elevation during the night and only a lesser peak around noon; thus, $Z_{\mathrm{oxy}}$ and $Z_{\text {therm }}$ were generally slightly deeper during the day. However, comparisons of $Z_{\text {oxy }}$ and $Z_{\text {therm }}$ at different times with Mann-Whitney $U$ tests did not yield any significant differences between day and night, whether tested for all 24-h series pooled together or tested separately.

\section{Community structure}

Highest vertically integrated abundance of the bulk zooplankton was found in April, with an average of 25,090 \pm
14,090 ind. $\mathrm{m}^{-2}$ at station 2 and 24,654 $\pm 12,867$ ind. $\mathrm{m}^{-2}$ at station 5. In August, zooplankton abundance was only $9,331 \pm 2,613$ ind. $\mathrm{m}^{-2}$ at station 2 . The vertically integrated bulk zooplankton abundance did not show any differences between day and night during any of the three 24-h series (Fig. 4).

The analysis of the vertical distribution showed that in April, the bulk zooplankton was accumulated in the upper layers. At station 2, in April, 91\% of all organisms were collected in the upper $20 \mathrm{~m}$ depth, and $89 \%$ of all organisms were collected in the upper $30 \mathrm{~m}$ depth at station 5 . Conversely, in August, zooplankton was distributed over all strata of the water column sampled (Fig. 4).

In April, weighted mean depth of the whole community varied from 6 to $25 \mathrm{~m}$. The percentage of the whole community found in the oxygenated upper layer $\left(P_{\text {oxy }}\right)$ varied from 68 to $88 \%$. In August, weighted mean depth of the whole community was clearly deeper than in April, varying from 40 to $77 \mathrm{~m}$, while $P_{\text {oxy }}$ was similar to April (67\%). Thus, in both periods, most of the zooplankton was generally found in the oxygenated layer. Weighted mean depth and $P_{\text {oxy }}$ were also used to compare the day and night hauls. The differences between day and night in weighted mean depth were significant for station 5 in April $(P=0.02$, $n=8)$ and at station 2 in August $(P=0.04, n=8)$, showing that the whole community was located near the surface at night and was located significantly deeper during the day on both occasions. Conversely, there were no significant differences in $P_{\text {oxy }}$ between day and night for the whole community, neither for any 24-h series nor for all series pooled together.

In April, Acartia tonsa dominated all multinet hauls at both stations, with $72.9 \%$ of the total abundance inshore, and $61.1 \%$ offshore (Table 1). In August, A. tonsa was still the most important species at the inshore station 2, with $42.7 \%$ of all organisms but at the offshore station 5, A. tonsa was virtually absent from the samples, and a completely different zooplankton community was found associated with the unusual Subtropical Waters. Therefore, the vertical distribution and migration of zooplankton at station 5 in August will not be analysed and discussed in detail. Accordingly, this study focuses on the zooplankton communities associated with $\mathrm{CCW}$ found in April at both stations and at station 2 in August.

Considering these three 24-h series together, Centropages brachiatus $(7.5 \%)$, E. inermis $(4.7 \%)$ and Paracalanus parvus $(3.1 \%)$ were also important among the catches (Table 1). Oncaea venusta was numerically dominant only in the 24-h series performed in August at station 2 (3.9\% of the total at this series). In the meroplankton, larvae of Magelona sp. (Polychaeta) were numerically dominant prominent in April, contributing $7.5 \%$ to the whole zooplankton at station 2 and $2.5 \%$ at station 5 (Table 1). Larvae 

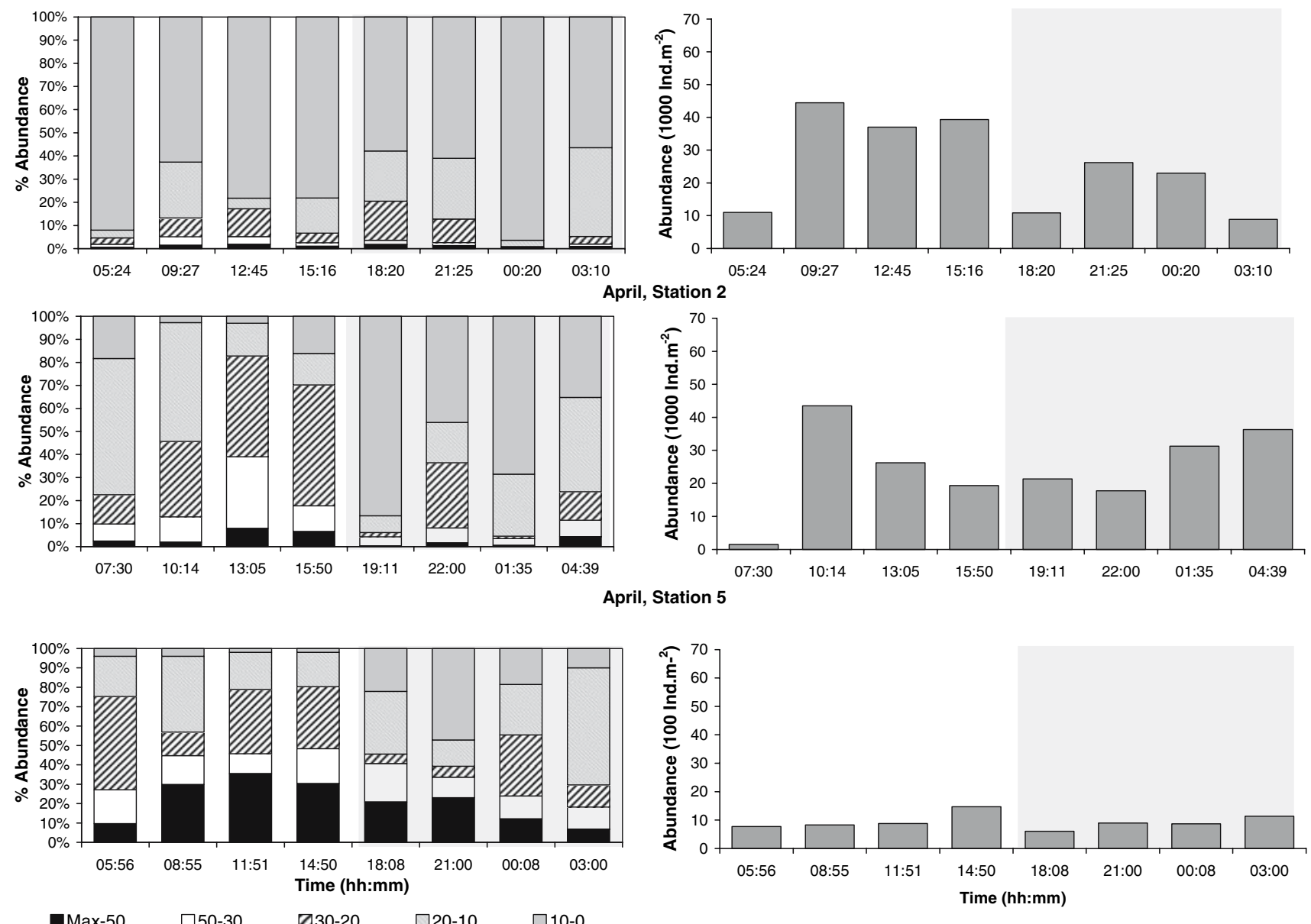

Fig. 4 Depth-integrated abundance of bulk zooplankton per stratum sampled off Central Peru in 2006. The shaded area indicates night samples

of Discinisca lamellosa (Brachiopoda) were also numerically dominant in April, contributing 3.5\% of the whole zooplankton at station 2. Larvae of both species were virtually absent in August. These conditions permitted the entrance of other meroplanktonic organisms such as eggs of Engraulis ringens (3.8\%, up to 350 ind. $\mathrm{m}^{3}$ ) and zoeae of Pleuroncodes monodon (6.4\%, up to 585.4 ind. $\mathrm{m}^{3}$ ).

The Shannon Weaver $\left(\mathrm{H}^{\prime}\right)$ species diversity of all three 24-h series ranged from low (0.5) to moderate (2.6), with an average of 1.9. Average evenness was 0.6 , with a minimum of 0.2 at $0-10 \mathrm{~m}$ depth and maximum of 0.8 at 30 $50 \mathrm{~m}$ depth during April.

Vertical distribution and ontogenetic migration

Most taxa, including adults of the dominant $A$. tonsa appear mainly in the oxygenated layers throughout the study period. Ninety-two percent of all A. tonsa adults were found at $0-30 \mathrm{~m}$ depth. When comparing the average vertical distribution of distinct life history stages of the most abundant copepod species, significant differences were found for A. tonsa only (Fig. 8). Average weighted mean depth of $A$. tonsa adults $(14 \pm 7.5 \mathrm{~m})$ was significantly shallower than weighted mean depth of nauplii $(25 \pm 12 \mathrm{~m})$ and copepodids $(33 \pm 14 \mathrm{~m})$ of this species. Copepodids were found with weighted mean depth down to $63 \mathrm{~m}$, and nauplii down to $52 \mathrm{~m}$, while adults generally displayed weighted mean depths above $20 \mathrm{~m}$, and never reached below $30 \mathrm{~m}$. This difference in weighted mean depth was significant for all three 24-h series pooled $(P=0.0001$, valid $n=19$ for copepodids, and $P=0.005$, valid $n=18$ for nauplii) and for both 24-h series in April. Copepodids of $A$. tonsa were generally found deeper than nauplii of this species, although average weighted mean depths of nauplii and copepodids were not significantly different when tested for all three 24-h series pooled together. However, $P_{\text {oxy }}$ of nauplii was significantly higher than $P_{\text {oxy }}$ of the copepodids of this species $(P=0.036$ valid $n=18)$, indicating that copepodids of $A$. tonsa were generally found in less-oxygenated waters than nauplii.

For E. inermis, another species where adults, copepodids, and nauplii were sufficient enough for testing hypotheses 
Table 1 Average, maximum and minimum values of abundance for the most abundant taxa

\begin{tabular}{lrrl}
\hline & $\begin{array}{l}\text { Avg. } \\
\text { (ind. } \mathrm{m}^{-3} \text { ) }\end{array}$ & $\begin{array}{l}\text { Max } \\
\text { (ind. } \mathrm{m}^{-3} \text { ) }\end{array}$ & $\begin{array}{l}\text { Min } \\
\text { (ind. } \mathrm{m}^{-3} \text { ) }\end{array}$ \\
\hline Acartia tonsa adults & 279.3 & 4393.7 & 0.3 \\
A. tons copepodids & 2.6 & 16.7 & 0.0 \\
A. tonsa nauplii & 2.8 & 25.6 & 0.1 \\
Calanus sp. & 1.0 & 4.4 & 0.2 \\
Calanus copepodids & 4.3 & 12.4 & 0.2 \\
Centropages brachiatus & 38.1 & 413.0 & 0.1 \\
Eucalanus inermis & 24.1 & 502.7 & 0.2 \\
E. nauplii & 18.9 & 326.7 & 0.1 \\
Coryceus dubius & 2.0 & 7.7 & 0.3 \\
Paracalanus parvus & 15.3 & 167.6 & 0.1 \\
Hemicyclops thalassius & 2.4 & 34.5 & 0.2 \\
Oithona sp. & 2.0 & 6.7 & 0.1 \\
Oncaea venusta & 6.6 & 49.1 & 0.0 \\
Discinisca lamellosa larvae & 24.4 & 253.3 & 0.1 \\
Limacina sp. larvae & 1.1 & 4.8 & 0.1 \\
Magelona sp. larvae & 32.2 & 323.1 & 0.1 \\
Oikopleura sp. & 10.1 & 250.5 & 0.1 \\
Pleopis polyphemoides & 1.3 & 1.3 & 1.3 \\
\hline & & & \\
\hline
\end{tabular}

related to ontogenetic vertical migration, no significant differences in weighted mean depth were found either between life history stages when tested for all three 24-h series pooled together, or for any 24-h series tested separately.

Diel vertical migration

Among the species and stages analysed, significant differences in weighted mean depth or $P_{\text {oxy }}$ between diurnal and nocturnal hauls were detected for several taxa. Centropages brachiatus and E. inermis were found deeper during the day (diel vertical migration) during one 24-h series. Paracalanus parvus and larvae of Magelona sp. were found deeper during the night (reverse diel vertical migration) in at least one series. For $P_{\text {oxy }}$, Hemicyclops thalassius, Oithona sp. and larvae of Magelona sp. were the only taxa to show significant diurnal variations.

Centropages brachiatus (adults and copepodids) showed significant diel vertical migration at station 2 in August $(P=0.02, n=8)$. During this 24 -h series, weighted mean depth for Centropages brachiatus was $18 \pm 1.6 \mathrm{~m}$ at night. During the day, this species migrated to a deeper stratum, to a depth of $34 \pm 2.5 \mathrm{~m}$.

E. inermis (adults and copepodids) also showed significant diel vertical migration at station 2 in August $(P=0.02$, $n=8$ ). During this 24 -h series, weighted mean depth for E. inermis was $32 \pm 4.5 \mathrm{~m}$ at night. During the day, this species also migrated to a deeper stratum, to a depth of $58 \pm 4.1 \mathrm{~m}$

Paracalanus parvus (adults and copepodids) showed significant reverse diel vertical migration at station 5 in April $(P=0.033$, valid $n=7)$. During this 24 -h series, weighted mean depth for $P$. parvus was $30 \pm 4.8 \mathrm{~m}$ at night. During the day, this species migrated upwards, with a depth of $22 \pm 1.5 \mathrm{~m}$.

Magelona sp. larvae showed significant reverse diel vertical migration at station 2 in April $(P=0.02$, valid $n=7)$, and for all three series pooled together $(P=0.001$, valid $n=23)$. Magelona sp. larvae were found at shallower depths during the day and migrated downwards during the night (Figs. 5, 6, 7, 8). Considering all hauls, weighted mean depth for Magelona sp. larvae was $37 \pm 15 \mathrm{~m}$ at night, while during the day the depth was $15 \pm 4 \mathrm{~m}$.

Comparisons of thermo- and oxycline depths $\left(Z_{\text {oxy }}\right.$ and $\left.Z_{\text {therm }}\right)$ at different times with Mann-Whitney $U$ tests did not yield any significant differences between day and night, whether tested for all three 24-h series pooled together or for each series tested separately. Thus, taxa that performed diel vertical migration did not simply follow the fluctuation in cline depths.

For E. inermis, adults and copepodids did not show a regular diel vertical migration pattern, except for station 2 in August. Additionally, this deep-dwelling species showed singular upward movements or "emersion" events. It did appear in considerable amounts above the oxycline $\left(P_{\text {oxy }}>50 \%\right)$ at one third of all multinet hauls. These upward movements were observed during day and night. Upward migration of $E$. inermis adults and copepodids was generally limited to the layer just above the thermocline. Neither during these singular movements nor during the migration at station 2 in August were peaks of E. inermis abundance ever seen in the upper two layers, above $20 \mathrm{~m}$ of depth (Figs. 5, 6, 7).

Diel vertical migration and environmental parameters

The main species showed significant correlations with at least some environmental parameters (Table 3). Adults of A. tonsa showed negative correlations with depth and salinity, according to their consistently higher abundances in shallow layers and lower abundances in high-salinity waters in August. There were no significant correlations with oxygen concentration or temperature for adults of A. tonsa. Several other taxa also showed negative correlations with depth (Calanus sp., Centropages brachiatus, Discinisca lamellosa larvae, Oikopleura sp., and Pleopis polyphemoides). No significant correlations with environmental parameters were found for nauplii and copepodids of A. tonsa. E. inermis (all stages) and Oncaea venusta were the only taxa to display positive correlations with depth, 
Fig. 5 24-h variation of the vertical distribution of selected species off Callao, station 2, during April 2006. Dotted lines indicate the approximate position of the oxycline, based on the $1-\mathrm{ml}^{-1}$ oxygen pycnocline
Fig. 6 24-h variation of the vertical distribution of selected species off Callao at station 5 during April 2006. Dotted lines indicate the approximate position of the oxycline, based on the $1-\mathrm{ml}^{-1}$ oxygen pycnocline
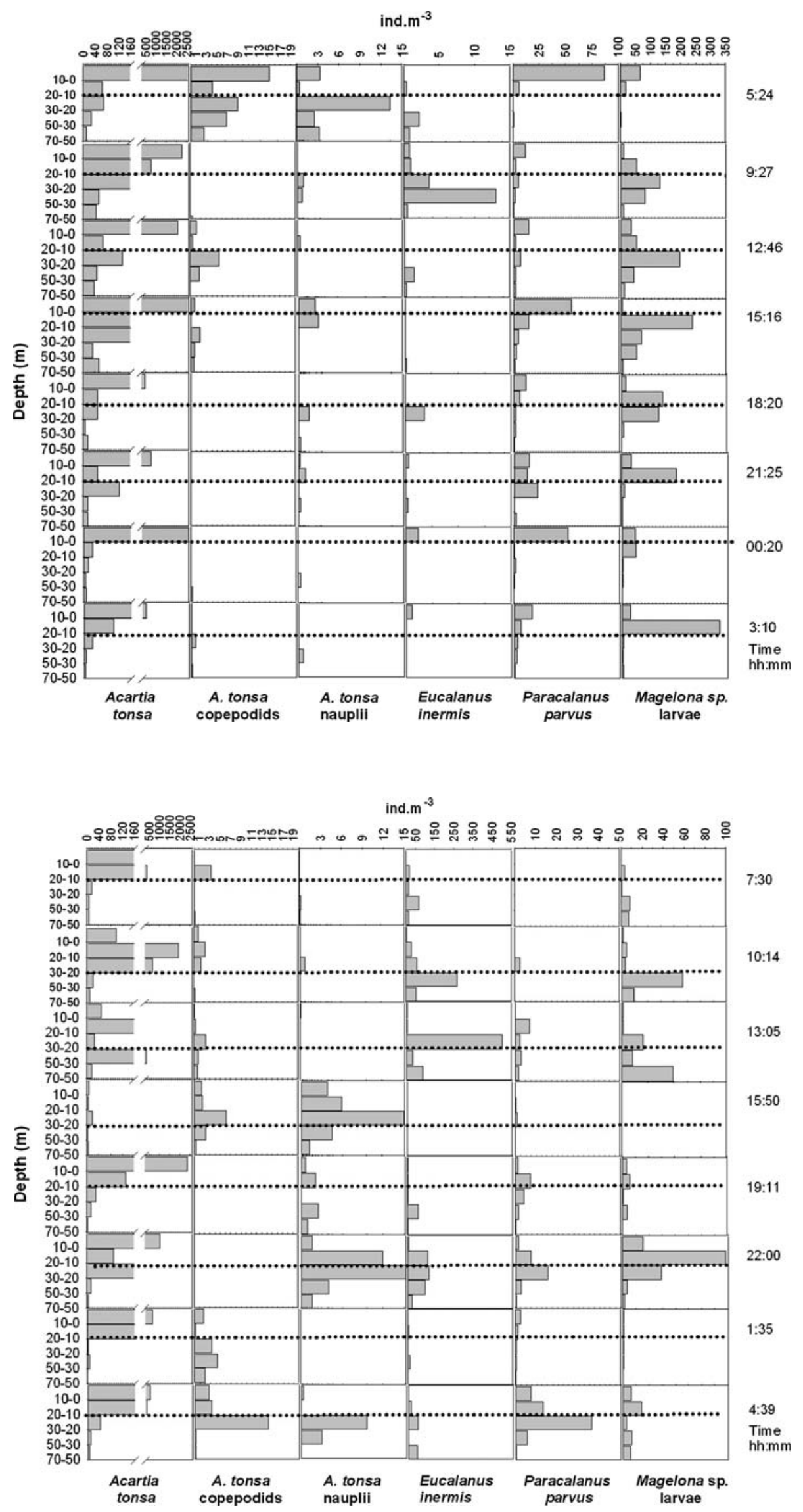
Fig. 7 24-h variation of the vertical distribution of selected species off Callao at station 2 during August 2006. Dotted lines indicate the approximate position of the oxycline, based on the 1 - $\mathrm{ml}^{-1}$ oxygen pycnocline

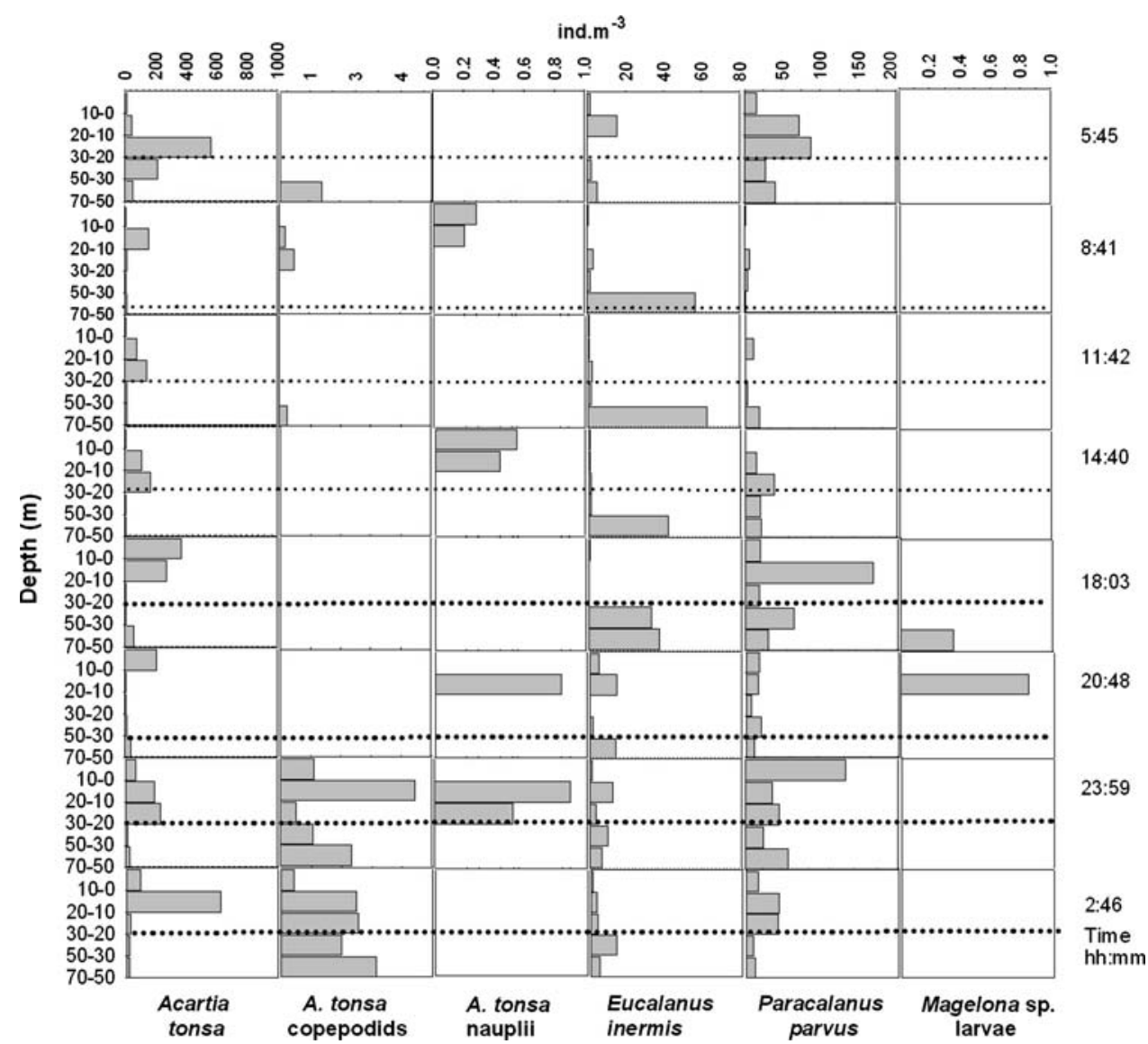

according to their consistently higher abundances in deep layers. E. inermis did not show any other significant correlations, while Oncaea venusta showed a positive correlation with salinity related to high salinities in August. Significant correlations were observed with temperature, laboratory-derived chlorophyll $a$ and oxygen concentrations for several taxa. Larvae of the polychaete Magelona sp. showed negative correlations with oxygen, laboratoryderived chlorophyll $a$, and with temperature. Adults and copepodids of Calanus sp., Coryceus dubius, Paracalanus parvus and Oithona sp. showed positive correlations with salinity, as they were more abundant in August, when highsalinity waters predominated (Table 2, Fig. 2).

The correlations between the depths of thermo- and oxyclines and weighted mean depth of the main taxa (Table 4) agreed well with the correlation matrix between abundance and absolute values of temperature an oxygen concentration (Table 3). P. parvus (all stages), which displayed positive correlations between absolute values and abundances, also showed positive correlations between cline depths and their weighted mean depths, confirming the importance of these variables in determining the vertical distribution. Many other taxa (A. tonsa adults, $C$. brachiatus adults and copepodids, Oikopleura sp., Hemyciclops thalassius adults and copepodids, adults of $P$. polyphemoides, and Magelona sp. larvae) showed positive correlations between weighted mean depth and cline depths, showing the importance of cline depths in determining depth regulation of these organisms. Among these organisms Magelona sp. larvae were the only taxa not to show significant correlation with depths of both clines, responding to $Z_{\text {therm }}$ only. This may be due to a clearly deeper thermocline at station 5 in comparison with station 2 in April (Fig. 2). Accordingly, in April, Magelona sp. larvae were deeper at station 5 (weighted mean depth: $39.5 \pm 16.8 \mathrm{~m}$ ) than at station 2 (weighted mean depth: $17.8 \pm 6.7$ ), which explains the positive correlation with $Z_{\text {therm }}$. On the other hand, there was no consistent difference in oxycline depth between stations 2 and 5 (Fig. 2), which explains the positive correlation with $Z_{\text {therm}}$. Weighted Mean Depths of deep-dwelling E. inermis (all stages) and copepodids and nauplii of $A$. tonsa did not show any significant correlations with cline depths.

Taxa that displayed correlations of weighted mean depth with cline depths did not show any correlation between the percentage found in the oxygenated layer $\left(P_{\text {oxy }}\right)$ and cline depth. This confirms that organisms that are restricted to the upper oxygenated layers (e.g. Oikopleura sp., Centropages brachiatus, Pleopis polyphemoides) display consistently high $P_{\text {oxy }}$ values, independent of cline depths. $P_{\text {oxy }}$ values of nauplii of $E$. inermis and nauplii and 
Fig. 8 Temporal variations of the weighed mean depth of adults and copepodids of Acartia tonsa and larvae of the polychaete Magelona sp. at two stations off Callao, Peru, during 2006
Time (hh:mm)

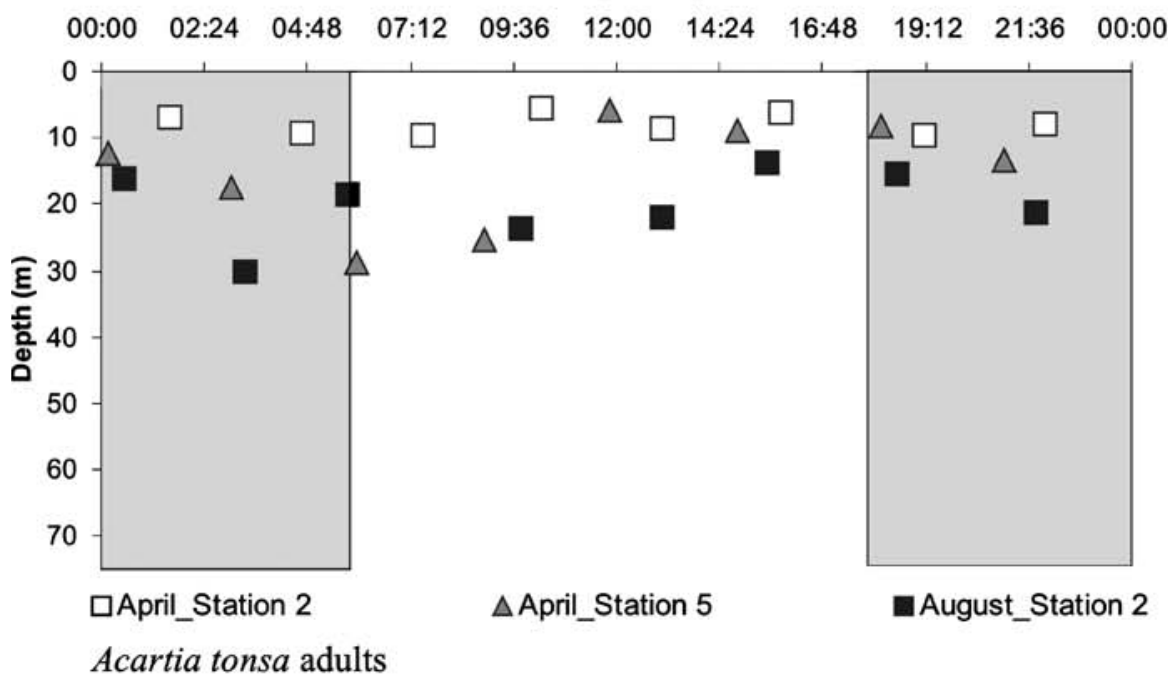

Time (hh:mm)

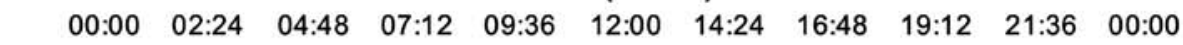

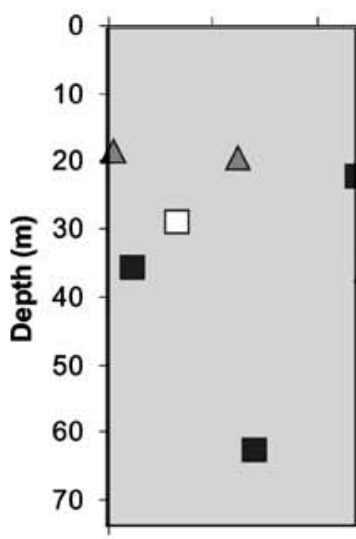

$\square$ April_Station 2 Acartia tonsa copepodids

$\triangle$ April_Station 5 $\triangle \square$

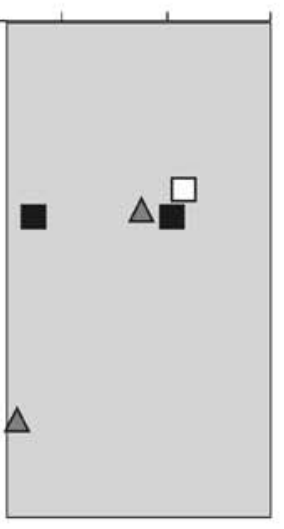

August_Station 2

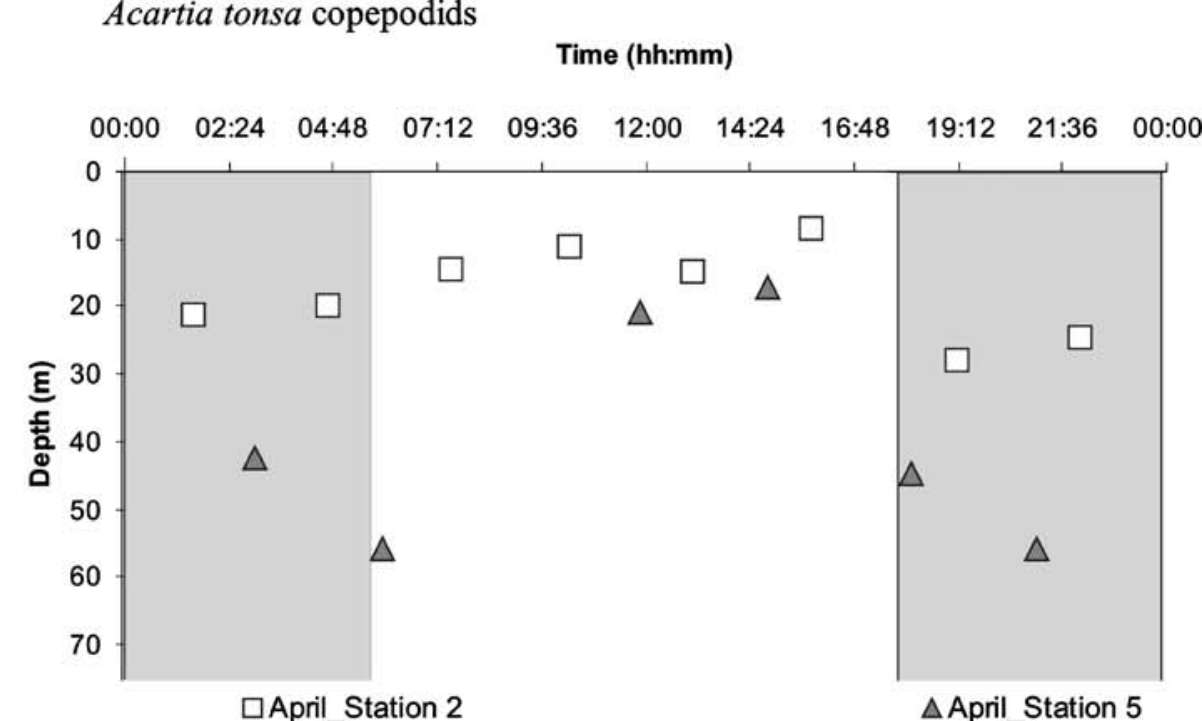

Magelona sp. Larvae 
Table 2 Mean percentage above the 1-ml $1^{-1}$ oxycline $\left(P_{\text {oxy }}\right)$, weighted mean depth (WMD) and standard deviation for the main taxa off Callao

\begin{tabular}{|c|c|c|c|c|c|c|c|c|c|c|c|c|}
\hline \multirow[t]{2}{*}{ Taxa } & \multicolumn{6}{|c|}{ Percentage at surface $\left(P_{\text {oxy }}\right)$} & \multicolumn{6}{|c|}{ Weighted mean deapth (WMD) } \\
\hline & $\begin{array}{l}\text { April } \\
\text { Station-2 } \\
(\%)\end{array}$ & $\begin{array}{l}\text { St. dev. } \\
(\%)\end{array}$ & $\begin{array}{l}\text { April } \\
\text { Station-5 } \\
(\%)\end{array}$ & $\begin{array}{l}\text { St. dev. } \\
(\%)\end{array}$ & $\begin{array}{l}\text { August } \\
\text { Station-2 } \\
(\%)\end{array}$ & $\begin{array}{l}\text { St. dev. } \\
(\%)\end{array}$ & $\begin{array}{l}\text { April } \\
\text { Station-2 }\end{array}$ & St. dev. & $\begin{array}{l}\text { April } \\
\text { Station-5 }\end{array}$ & St. dev. & $\begin{array}{l}\text { August } \\
\text { Station-2 }\end{array}$ & St. dev. \\
\hline Acartia tonsa & 92 & 4.5 & 89 & 8.9 & 88 & 17.4 & 7.9 & 1.6 & 15.0 & 8.2 & 20.1 & 5.3 \\
\hline A. tonsa copepodids & 15 & 20.0 & 51 & 37.9 & 58 & 28.6 & 26.7 & 4.6 & 29.1 & 13.3 & 40.1 & 16.3 \\
\hline A. tonsa nauplii & 30 & 40.0 & 100 & 0.0 & 81 & 26.2 & 27.1 & 11.1 & 31.2 & 10.6 & 13.1 & 4.6 \\
\hline Calanus sp & & & 73 & 27.9 & & & & & & & & \\
\hline Calanus copepodids & & & 70 & 42.1 & & & & & & & & \\
\hline Centropages brachiatus & 89 & 21.4 & 75 & 22.9 & 80 & 28.5 & & & & & & \\
\hline Eucalanus inermis & 34 & 44.3 & 32 & 29.4 & 36 & 26.9 & 7.6 & 2.5 & 18.7 & 9.8 & 26.3 & 8.5 \\
\hline Eucalanus nauplii & & & 18 & 19.9 & 31 & 39.8 & 25.3 & 16.2 & 40.8 & 11.9 & 45.0 & 14.2 \\
\hline Coryceus dubius & & & 80 & 14.4 & & & & & 39.1 & 14.0 & 49.6 & 7.3 \\
\hline Paracalanus parvus & 75 & 16.4 & 68 & 16.8 & 65 & 26.5 & 12.8 & 4.8 & 26.3 & 5.5 & 29.6 & 6.8 \\
\hline Hemicyclops thalassius & 53 & 26.3 & 49 & 44.1 & 92 & 10.7 & 20.0 & 4.6 & 20.4 & 5.3 & 40.5 & 14.7 \\
\hline Oithona sp. & & & 65 & 13.0 & 69 & 45.5 & & & & & & \\
\hline Oncaea venusta & & & 38 & 27.7 & 60 & 37.9 & & & & & 25.2 & 6.9 \\
\hline $\begin{array}{l}\text { Discinisca lamellosa } \\
\text { larvae }\end{array}$ & 81 & 30.7 & & & 71 & 48.1 & 10.6 & 2.7 & & & & \\
\hline Limacina sp. & 92 & 20.9 & 46 & 44.1 & 37 & 26.8 & 6.2 & 0.8 & 21.1 & 6.4 & 21.5 & 13.1 \\
\hline Magelona sp. larvae & 55 & 37.8 & 50 & 70.7 & 70 & 26.9 & 17.8 & 6.7 & 39.5 & 16.8 & & \\
\hline Oikopleura sp. & 97 & 1.6 & 90 & 26.1 & 89 & 21.2 & & & & & & \\
\hline Pleopis polyphemoides & 97 & 2.6 & & & & & 7.1 & 2.4 & 11.3 & 8.4 & & \\
\hline Total zooplankton & 88 & 7.2 & 68 & 12.2 & 67 & 30.8 & 9.4 & 2.3 & 21.9 & 8.0 & 56.6 & 14.1 \\
\hline
\end{tabular}

Table 3 Spearman rank correlation matrix for the main abiotic parameters and the most abundant taxa. Values are only for shown for significant correlations $(p<0.05)$

\begin{tabular}{|c|c|c|c|c|c|}
\hline & Depth & $\begin{array}{l}\text { Oxygen } \\
\left(\mathrm{ml} \mathrm{l}^{3}\right)\end{array}$ & $\begin{array}{l}\text { Chlorophyll } \\
a\left(\mu 11^{-1}\right)\end{array}$ & Temp. & Salinity \\
\hline Acartia tons $a$ adults & -0.52 & NS & NS & NS. & -0.2 \\
\hline A. tons $a$ copepodids & NS & NS & NS & NS & NS \\
\hline A. tonsa nauplii & NS & NS & NS & NS & NS \\
\hline Calanus sp. adults & NS & NS & NS & 0.22 & 0.3 \\
\hline Calanus copepodids & -0.39 & NS & NS & 0.4 & 0.43 \\
\hline Centropages brachiatus adults & -0.3 & 0.52 & NS & NS & NS \\
\hline Eucalanus inermis adults and copep. & 0.33 & NS & NS & NS & NS \\
\hline Eucalanus inermis nauplii & 0.28 & NS & NS & NS & NS \\
\hline Coryceus dubius adults & NS & 0.35 & 0.54 & 0.41 & 0.35 \\
\hline Paracalanus parvus adults and copep. & NS & 0.3 & 0.4 & 0.31 & 0.28 \\
\hline Hemicyclops thalassius adults & NS & NS & NS & -0.2 & NS \\
\hline Oithona sp. adults & NS & 0.34 & 0.51 & 0.39 & 0.49 \\
\hline Oncaea venusta adults & 0.25 & NS & NS & NS & 0.23 \\
\hline Discinisca lamellosa larvae & -0.28 & NS & NS & NS & NS \\
\hline Limacina sp. adults & NS & 0.27 & NS & NS & NS \\
\hline Magelona sp. larvae & NS & -0.35 & -0.51 & -0.29 & NS \\
\hline Oikopleura sp.adults & -0.34 & NS & NS & NS & -0.25 \\
\hline Pleopis polyphemoides adults & -0.38 & NS & NS & NS. & 0.43 \\
\hline
\end{tabular}

copepodids of $A$. tonsa displayed significant positive correlations and cline depths, showing that larger amounts of these deep-dwelling organisms occurred in the oxygenated layers when clines moved downwards, thus indicating that oxygen and temperature clines are not the effective borders for these organisms. 
Table 4 Spearman rank correlation matrix for the depth of the oxycline $\left(Z_{\text {oxy }}\right)\left(1 \mathrm{ml} \mathrm{l}^{-1}\right)$, the depth of the thermocline $\left(Z_{\text {therm }}\right)\left(15^{\circ} \mathrm{C}\right)$, and the weighted mean depth (WMD) and percentage found in the oxygenated layer $\left(P_{\text {oxy }}\right)$ for the most abundant and frequent taxa

\begin{tabular}{|c|c|c|}
\hline & $Z_{\text {oxy }}$ & $Z_{\text {therm }}$ \\
\hline$Z_{\text {oxy }}$ & NS & 0.81 \\
\hline WMD A. tonsa adults & 0.67 & 0.82 \\
\hline WMD A. tonsa copep. & NS & NS \\
\hline WMD A. tonsa nauplii & NS & NS \\
\hline WMD E. inermis adults & NS & NS \\
\hline WMD C. brachiatus adults \& copep. & 0.63 & 0.80 \\
\hline WMD $P$. parvus adults \& copep. & 0.47 & 0.76 \\
\hline WMD Magelona sp. larvae & NS & 0.64 \\
\hline WMD Oikopleura sp. & 0.53 & 0.70 \\
\hline WMD $H$. thalassius adults \& copep. & 0.48 & 0.53 \\
\hline WMD $P$. polyphemoides & 0.59 & 0.74 \\
\hline $\mathrm{P}_{\mathrm{oxy}} A$. tonsa adults & NS & NS \\
\hline $\mathrm{P}_{\mathrm{oxy}}$ A. tonsa copep. & 0.60 & NS \\
\hline $\mathrm{P}_{\text {oxy }}$ A. tonsa nauplii & 0.60 & 0.70 \\
\hline $\mathrm{P}_{\text {oxy }}$ E. inermis adults & NS & NS \\
\hline $\mathrm{P}_{\text {oxy }}$ E. inermis nauplii & 0.57 & NS \\
\hline $\mathrm{P}_{\text {oxy }}$ C. brachiatus adults \& copep. & NS & NS \\
\hline $\mathrm{P}_{\text {oxy }} P$. parvus adults \& copep. & NS & NS \\
\hline $\mathrm{P}_{\text {oxy }}$ Magelona sp. larvae & NS & NS \\
\hline $\mathrm{P}_{\text {oxy }}$ Oikopleura sp. & NS & NS \\
\hline $\mathrm{P}_{\text {oxy }}$ Limacina $\mathrm{sp}$. & NS & 0.89 \\
\hline $\mathrm{P}_{\text {oxy }}$ H. thalassius adults \& copep. & NS & NS \\
\hline $\mathrm{P}_{\text {oxy }}$ Discinisca lamellosa larvae & NS & NS \\
\hline $\mathrm{P}_{\text {oxy }} P$. polyphemoides & NS & NS \\
\hline
\end{tabular}

$N S$ not significant $(P>0.05)$, Copep. copepodids

\section{Discussion}

Dynamics of water masses and zooplankton community

The hydrographic conditions found in this study reflect two very distinct situations: (1) the predominance of $\mathrm{CCW}$ and a shallow oxycline found in April 2006, associated to upwelling events found during non-El Niño conditions in this region (Morón 2000) and (2) the occurrence near the coast of highly oxygenated SSW in August 2006, which off Central Peru are more often located in oceanic areas.

Conditions found in April 2006 reflect the "typical" situation for neritic waters off Peru and the presence of CCW and upwelling events (Zuta and Guillen 1970) with extremely shallow ( $<20 \mathrm{~m}$ ) oxy- and thermoclines, which become deeper towards offshore. The vertical distribution of chlorophyll $a$ near the coast generally presents maximum values in the upper layers (Calienes and Guillen 1981). Previous studies off Callao show the maximum concentrations of chlorophyll $a$ in autumn (up to $9 \mu \mathrm{g} \mathrm{l}^{-1}$ ), and the minimum values under the influence of $\mathrm{SSW}\left(<1 \mu \mathrm{g}^{-1}\right)$ (Calienes and Guillen 1981), and also suggest the low abundance of phytoplankton during August in the area (S. Sanchez, personal communication).

The observed small-scale variations in salinity below 20-30 m (Fig. 2) are common feature of CTD profiles in this region. One potential explanation is that the huge temperature gradients in the thermocline and the different response times of conductivity and temperature sensors may be generating these salinity peaks, which are often simply smoothed out of the data.

The conditions observed in August 2006 (austral winter), are very different from the expected maximum winddriven upwelling events that determine the presence of $\mathrm{CCW}$, characterized by low surface temperatures (14$18^{\circ} \mathrm{C}$ ) and low salinities (34.9-35.0) in nearshore shelf waters (Morón 2006). In fact, the SSW, which in winter is usually located far offshore in oceanic areas, appear to be projected onto the coast. In this region, SSW show large horizontal and vertical fluctuations and approach the coast mainly during summer and also during El Niño conditions (Morón 2006). During winter of 2006 the SSW presence off Callao could be associated with the propagation of Equatorial Kelvin Waves (EKW) and their impact on the local water column conditions as coastally trapped waves (CTW). EKW and resulting CTW are more frequent and stronger during El Niño, but may also occur during non-El Niño periods. The analysis of the large-scale ENSO (El Niño Southern Oscillation) cycle, as given by the Multivariate ENSO Index MEI (Wolter and Timlin 1998) shows that in 2006, conditions switched from weak La Niña conditions in April (MEI: -0.6) to weak El Niño conditions in August (MEI: 0.75). Thus, the onset of the weak El Niño 2006/ 2007 could also explain the unusually warm and high-salinity SSW found in August 2006. Furthermore, EKW and CTW have been reported to be appearing in this region with a higher intensity since 2002 .

This change in the hydrographic conditions between April and August determine significant changes in the mesozooplankton community. In fact, during April the community was characterized by low to moderate diversity, dominated by Acartia tonsa, which has been considered typical for neritic waters in this region (Santander 1981; Giron 2001; Criales-Hernandez et al. 2006). In August, environmental conditions were not favourable for A. tonsa, and rather warmwater and offshore shelf taxa such as $P$. parvus, Oithona spp. and Corycaeus sp. became more abundant in the area. The decrease in A. tonsa abundance nearshore, and the disappearance of this key species in the offshore station in August, is certainly associated with the observed occurrence of SSW, which are found in oceanic areas much farther offshore under normal conditions. 
Diel vertical migration and oxygen minimum layer dynamics

On a diurnal time scale, the hydrographic conditions also showed some variability, as shown by the oscillations of thermo- and oxycline depths $\left(Z_{\text {therm }}\right.$ and $\left.Z_{\text {oxy }}\right)$. This variability could be related to internal waves that may affect the vertical dynamics of zooplankton (Pineda 1999; Johnson and Shanks 2002; Rinke et al. 2007). The apparent semidiurnal frequency of the observed oscillations indicates tidal forcing of these internal waves, although local surface tidal amplitude is less than $1 \mathrm{~m}$.

The observed oscillations in cline depths may be stimulating, or at least enhancing, the "regular" diel vertical migration (descent in the early morning) observed for Centropages brachiatus. C. brachiatus showed a diurnal variation in vertical distribution at station 2 in August and also at a series with considerable oscillations in cline depth. Accordingly, no diel vertical migration of any taxa was detected at station 2 in April when cline oscillations were minimal, thus supporting the assumption that diel vertical migration was related to cline oscillations. The results of the correlation analysis also support this idea, since weighted mean depths of $C$. brachiatus were significantly correlated with thermo- and oxycline depths. Furthermore, the abundance of $C$. brachiatus was significantly correlated to oxygen concentration, showing the importance of this factor in determining the distribution of this species. On the other hand, thermo- and oxycline depths $\left(Z_{\text {oxy }}\right.$ and $\left.Z_{\text {therm }}\right)$ oscillated at a higher frequency $(12 \mathrm{~h})$ than diel vertical migration, and there were no significant differences between day and night in cline depths. Thus, taxa that performed diel vertical migration did not simply follow the fluctuation in cline depths.

Two explanations are possible for the observed relation between cline depths and diel vertical migration of $C$. brachiatus: (1) this species may be stimulated or triggered by cline oscillations, possibly together with other factors (e.g. light, feeding) or (2) for taxa that are not adapted to hypoxia the descent of the oxycline gives room for migration into the upper, well-oxygenated layer. This space may then be constricted in regular intervals by cline oscillations. This constriction hypothesis would also explain the absence of any diel vertical migration of this species at station 2 in April, when the oxycline was most shallow. Conversely, Peterson (1998) found no diel vertical migration for these species. Although the data seem to show quite straightforwardly the existence of diel vertical migration for these taxa, the vertical distribution could be explained by physical processes. For example, changes in vertical distribution may also be generated by the advection of different water masses with different distributions of organisms. Unless each organism can be tagged and followed individually for relevant periods of time, this last residual uncertainty will always remain in any field study on zooplankton vertical migration. Many uncertainties still remain, but the results of our study confirm that diel vertical migration is a very flexible behaviour that can be adopted by planktonic organisms depending on environmental conditions, especially on oxygen minimum layer depth.

The vertical distribution of different life history stages of A. tonsa revealed a pattern of ontogenetic vertical migration. Adults were observed at surface and copepodids and nauplii were observed occupying mostly the deep anoxic layer. Although it might be questionable whether quantitative abundance data for small-sized stages such as nauplii can be obtained with $300-\mu \mathrm{m}$ nets, the massive occurrence of $A$. tonsa nauplii in the nets used below the oxycline is a clear evidence for their existence in these deeper strata. $A$ tonsa might show aggregations at various depths for reproduction. The existence of such layers seems to be an essential element of spatial structure of the plankton community (Longhurst 1981; Vinogradov 1997). This ontogenic vertical migration has obvious implications for the retention of A. tonsa populations in this highly advective and stratified environment with strong undercurrents (Smith et al. 1981a; Peterson 1998).

Meroplankton and reverse diel vertical migration

In our study, most invertebrate larvae stayed permanently in the oxygenated upper layers, with the notable exception of the larvae of the polychaete Magelona sp., which performed reverse diel vertical migration. For meroplanktonic larvae, high temperature and food abundance found in the upper layers may be used to maximise growth and reduce the time spent in the plankton (Neill 1992; Gray and Kingsford 2003; Irigoien et al. 2004), rather than engaging in diel vertical migration at the risk of prolonging the planktonic phase.

Reverse diel vertical migration (i.e. ascent at the beginning of daytime) has not yet been reported for this region. This inverse pattern has been observed for the copepods Pseudocalanus sp. off the Northwestern USA, concurrently with a normal vertical migration by nocturnal invertebrate predators (Ohman et al. 1983; Ohman 1990), Ohman et al. (1983) suggested that predator avoidance was the clue for this migratory behaviour. In the Antarctic, adults and juveniles of Euphausia superba migrate upwards to feed on phytoplankton during the day, and downwards during the night to feed on zooplankton (Hernández-León et al. 2001). The authors hypothesized that krill displayed reverse vertical migration to avoid predation by mesopelagic fishes. The unusual reverse diel vertical migration pattern observed for larvae of Magelona sp. may also be related to the avoidance of vertically 
migrating predators, although overall vulnerability to visual predators should be higher when ascending at daytime. Another possible explanation for this reverse diel vertical migration could be associated with its feeding strategy (Kepplel et al. 1985; Vinogradov 1997), and to a possible strategy of larval retention and transport, utilising deep undercurrents (Wing et al. 1998; Mace and Morgan 2006; Yannicelli et al. 2006).

\section{Comparisons with previous studies}

Several other authors have suggested the existence of vertical migration in this area (Judkins 1980; Boyd et al. 1981; Mackas et al. 1981; Smith et al. 1981a; Glebov 1982; Semenova et al. 1982). The vertical distribution of copepods shows similarities and differences with previous data. Judkins (1980) previously described vertical distribution relative to the oxygen minimum layer in Peru from samples collected at $15^{\circ} \mathrm{S}$ in shelfbreak, slope, and offshore. Most zooplankton taxa were in concentrations exceeding $1.0 \mathrm{ml}^{-1}$ throughout the upper $85 \mathrm{~m}$. Similar patterns were also described for zooplanktonic taxonomic group off $9^{\circ} \mathrm{S}$ by (Mackas et al. 1981). Zooplankton did not exceed 30-m depth and zooplankton peak was coincident with the sharp gradient in dissolved oxygen concentration. Saltzman and Wishner (1997) examined the vertical distribution of copepods in the eastern tropical Pacific, and showed how copepods have modified vertical distribution in regions with pronounced midwater oxygen minimum zones and displayed different environments. Several deep-sea animals have modified metabolic systems adapted to survival in water with low oxygen availability (Childress and Thuessen 1992).

The vertical distribution of several species suggests a possible niche separation of closely related species in the extreme conditions of the oxygen minimum layer (Saltzman and Wishner 1997). E. inermis had the greatest vertical distribution in eastern equatorial Pacific (Fleminger 1973); but in a study off Chile, E. inermis remained near the base of the oxyclyne and within the upper zone of the oxygen minimum zone (Hidalgo et al. 2005). In the waters off Peru, Boyd et al. (1981) and Mackas et al. (1981) showed that Eucalanus could withstand periods of $12 \mathrm{~h}$ in anoxic layers. Judkins (1980), when testing vertical distribution between day and nights, found significant differences at shelfbreak and offshore stations for E. inermis only, thus showing the occurrence of diel vertical migration for this species, similar to the results of the present study. During the present study, the population of E. inermis was generally located below the oxycline, a strategy, which allows for rapid incursions into oxygenated layers immediately above the oxygen minimum layer (Figs. 5, 6, 7). This pattern may be related to the avoid- ance of predators, which are limited to oxygenated layers (e.g. anchovies).

\section{Conclusions}

The zooplankton off the coast of Central Peru was characterized by marked temporal and spatial heterogeneity, but governed by clear processes and behavioural traits, which could be related to the dynamics of the oxygen minimum layer as follows: (1) the total bulk holo- and meroplankton and most taxa were concentrated in the upper oxigenated waters, above the oxygen minimum layer; (2) abundance decreased from April to August due to the increasing influence of SSW; (3) bulk zooplankton and most taxa displayed a wider vertical distribution in the water column in August, clearly following the deepening of the oxygen minimum layer, and 4) average abundances and weighted mean depths of many taxa were correlated to oxygen concentration and oxycline depth, showing the importance of cline dynamics for this community.

Furthermore, five distinct patterns of vertical distribution and migration in relation to the oxygen minimum layer were distinguished in this study: (1) ontogenetic vertical migration through the oxycline (Acartia tonsa adults, nauplii, and copepodids), (2) permanent limitation to layers above the oxycline (e.g. Oikopleura sp., most invertebrate larvae), (3) distribution mostly below the oxycline with occasional immigration into the layers just above the oxycline (E. inermis), (4) diel vertical migration, (e.g. Centropages brachiatus at one station), and (5) reverse diel vertical migration (e.g. larvae of the polychaete Magelona sp.).

Our results have clear implications for the understanding of the retention mechanisms of key zooplankton taxa in an extremely advective environment (Smith et al. 1981a, b) and for prey-predator relationships in the pelagic realm of the Humboldt Current System. The shelf areas of the Humboldt Current System are extremely productive, but display considerable dynamics on several spatial and temporal scales. This study provides evidence that in spite of the high variability in abundance and distribution of the observed communities, changes in oxycline dynamics have predictable effects on zooplankton vertical distribution in the these coastal waters.

Acknowledgments This paper forms part of the Ph.D. thesis of the first author, at Bremen University. Financial support was granted by the frame of the EU-project CENSOR (Climate variability and El Niño Southern Oscillation: implications for natural coastal resources and management, contract 511071) and this is CENSOR publication 0106. The first author was partially supported by a short-term scholarship from Deutscher Akademischer Austauschdienst (DAAD). The authors are grateful to crew of the R/V Olaya, to the participants of the cruises who helped in sample collection and to the Area de Evaluación Secundaria Laboratory of IMARPE for logistical support, help in identifying 
zooplankton, and unconditional friendship in Lima. The authors also thank Dr. Cathy Lucas, Dr. Luis Giménez, and an anonymous reviewer for improving the original text with important comments and suggestions.

\section{References}

Albornoz L, Wehrtmann IS (1997) Descripción y clave de los primeros estadios larvales de camarones carídeos (Decapoda: Hippolytidae, Alpheidae, Rhynchocinetidae) de aguas costeras de Chile. Invest Mar Valparaíso 25:121-133

Alheit J, Niquen M (2004) Regime shifts in the Humboldt current ecosystem. Prog Oceanogr 60:201-222

Antezana T (2002) Vertical distribution and diel migration of Euphausia mucronata in the oxygen minimum layer of the Humboldt Current. Oceanogr Eastern Pacific II:13-28

Banse K, Hobson KD (1974) Principal external diagnostic characters of families of benthic errantiate Polychaetes. Bull Fish Res Board Can, pp 11-19

Boyd CM, Smith SL, Cowles TJ (1981) Grazing patterns of copepods in the upwelling system off Peru. Bol Inst Mar Peru, pp 144-154

Brink K, Halpern D, Huyer A, Smith R (1980) Near-shore circulation near $15^{\circ} \mathrm{S}$ : the physical environment of the Peruvian upwelling system. Elsevier, Amsterdarm

Calienes R, Guillen O (1981) Masas de agua y producción primaria en el Perú. In: Investigación cooperativa de la anchoveta y su ecosistema. Bol Inst Mar Peru Vol Extraord, pp 130-144

Carrasco S, Lozano O (1989) Seasonal and long-term variations of zooplankton volumes in the Peruvian sea, 1964-1987. Instituto del Mar del Peru (IMARPE), Deutsche Gesellschaft für Technische Zusammenarbeit (GTZ) and International Center for Living Aquatic Resources Mangement (ICLARM), Manila

Chavez FP, Ryan J, Lluch-Cota SE, Niquen M (2003) From anchovies to sardines and back: multidecadal change in the Pacific Ocean. Science 299:217-221

Childress JJ, Thuessen EV (1992) Metabolic potential of deep-sea animals: regional and global scales. Kluwer, Dordrecht

Cohen JH, Forward RB Jr. (2002) Spectral sensitivity of vertically migrating marine copepods. Biol Bull 203:307-314

Criales-Hernandez MI, Graco M, Ayón P, Flores G, Schamborn R, Hirche H-J, Wolff M (2006) temporal variability of the mesozooplankton community in the Humboldt Upwelling System off Central Peru International Conference on the Humboldt Current System, 27 Nov-2 Dec, Published by. IMARPE, IRD and FAO, Lima, pp 151

Escribano R (2006) Zooplankton interactions with the oxygen minimun zone in the eastern south pacific. Supl Gayana 70:19-21

Fleminger A (1973) Pattern, number, variability, and taxonomic significance of integumental organs (sencilla and glandular pores) in the genus Eucalanus (Copepoda Calanoida). Fish Bull 71:965-1010

Flint MV (1975) Trophic structure and vertical distribution of trophic groups of mesoplankton of the Equator $\left(97^{\circ} \mathrm{W}\right)$. Oceanol 102:238-244

Flint MV, Drits AV, Pasternak AF (1991) Characteristic features of body composition and metabolism in some interzonals copepods. Mar Biol 111:199-205

Giron M (2001) Zooplancton e ictioplancton durante el crucero oceanográfico regional Conjunto 0005-06. Inf Inst Mar Perú 163:47-57

Glebov BV (1982) Diurnal variations in the vertical distribution of zooplankton in Coastal Peru waters. Seriya biol 3:6-11

Gray CA, Kingsford MJ (2003) Variability in thermocline depth and strength, and relationships with vertical distributions of fish larvae and mesozooplankton in dynamic waters coastal waters. Mar Ecol Prog Ser 247:211-224
Gurney R (1942) The larvae of decapod Crustacea. Ray Soc Publ 129:1-306

Haury LR, Wiebe PH, Orr MH, Briscoe MG (1983) Tidally generated high-frequency internal wave packets and their effects on plankton in Massachusetts Bay. J Mar Res 41:65-112

Hays GC (2003) A review of the adaptive significance and ecosystem consequences of zooplankton diel vertical migrations. Hydrobiol 503:163-170

Heinrich AK (1973) Horizontal distribution of copepods in the Peru Current region. Oceanol 13:94-103

Hernández-León S, Almeida CG, Torres SM, Portillo-Hahnefeld A (2001) Zooplankton biomass and indices of feeding and metabolism in island-generated eddies around Gran Canaria. J Mar Syst 30:51-66

Hidalgo P, Escribano R, Morales CE (2005) Ontogenetic vertical distribution and diel migration of the copepod Eucalanus inermis in the oxygen minimun zone off northern Chile (20-21 $\left.{ }^{\circ} \mathrm{S}\right)$. J Plankt Res 27:519-529

Holm-Hansen A, Lorenzen C, Holmes R, Strickland J (1965) Fluorometric determination of chlorophyll. J Cons Perm Expl 30:3-15

Irigoien X, Conway DVP, Harris RP (2004) Flexible diel vertical migration behaviour of zooplankton in the Irish Sea. Mar Ecol Prog Ser 267:85-97

Johnson J, Shanks AL (2002) Time series of the abundance of the postlarvae of the crabs Cancer magister and Cancer spp. on the southern Oregon coast and their cross-shelf transport. Estuaries 25:1138-1142

Judkins D (1980) Vertical distribution of zooplankton in relation to the oxygen minimum off Peru. Deep Sea Res 27A:475-487

Kepplel GS, Willbanks L, Piepper RE (1985) Diel variation in body carontenoid content and feeding activity in marine zooplankton assamblages. J Plankt Res 7:569-580

Longhurst AR (1967) Vertical distribution of zooplankton in relation to the eastern Pacific oxygen minimun. Deep Sea Res 14:51-63

Longhurst AR (1981) Significance of spatial variability. Academic, London

Mace AJ, Morgan SG (2006) Biological and physical coupling in the lee of a small headland: Contrasting transport mechanisms for crab larvae in an upwelling region. Mar Ecol Prog Ser 324:185196

Mackas DL, Boyd CM, Smith S, Santander H (1981) Vertical distributions of plankton in the upper $35 \mathrm{~m}$ of the Peruvian upwelling zone-application o a shipboard electronic plankton counting system. Bol Inst Mar Peru, pp 67-71

McManus MA, Cheriton OM, Drake PJ, Holliday DV, Storlazzi CD, Donaghay PL, Greenlaw CF (2005) Effects of physical processes on structure and transport of thin zooplankton layers in the coastal ocean. Mar Ecol Prog Ser 301:199-215

Morón O (2000) Caracteristicas del ambiente marino frente a la costa peruana. Bol Inst Mar Peru 19:179-204

Morón O (2006) Monthly sea surface salinity by marsden squares off the Peruvian coast (1960-2004). International Conference on the Humboldt Current System. IMARPE, IRD and FAO, Lima, pp 104

Neill WE (1992) Population variation in the ontogeny of predator-induced vertical migration of copepods. Nature 356:55-57

Ohman MD (1990) The demographic benefits of diel vertical migration by zooplankton. Ecol Monogr 60:257-281

Ohman MD, Frost BW, Cohen EH (1983) Reverse diel vertical migration-an escape from invertebrate predators. Science 220:14041407

Pearre S (2003) Eat and run? The hunger/satiation hypothesis in vertical migration: history, evidence and consequences. Biol Rev 78:1-79

Peterson W (1998) Life cycle strategies of copepods in coastal upwelling zones. J Mar Syst 15:313-326 
Pillar SC, Armstrong DA, Hutchings L (1989) Vertical migration, dispersal and transport of Euphasia ludens in the southern Benguella current. Mar Ecol Prog Ser 53:179-190

Pineda J (1999) Circulation and larval distribution in internal tide bore warm fronts. Limnol Oceanogr 44:1400-1414

Pizarro O, Shaffer G, Dewitte B, Ramos M (2002) Dynamics of seasonal and interannual variability of the Peru-Chile Undercurrent. Geophys Res Let 29. doi:10.1029/2002GL014790

Pohle G, Fransozo A, Negreiros-Fransozo ML, Medina FL (1999) Larval Decapoda (Brachyura). Backhuys, Leiden

Renz J, Hirche H-J (2006) Life cycle of Pseudocalanus acuspes Giesbrecht (Copepoda, Calanoida) in the Central Baltic Sea: I. Seasonal and spatial distribution. Mar Biol 148:567-580

Rinke K, Hubner I, Petzoldt T (2007) How internal waves influence the vertical distribution of zooplankton. Freshw Biol 52:137-144

Roe HSJ, Angel MV, Badcock J, Domanski P, James PT, Pugh PR, Thurston MH (1984) The diel migrations, distributions within a mesopelagic community in the North East Atlantic. 1. Introduction, sampling procedures. Prog Oceanogr 13:189-199

Saltzman J, Wishner K (1997) Zooplankton ecology in the eastern tropical Pacific oxygen minimum zone above a seamount: 2 . Vertical distribution of copepods. Deep Sea Res I 44:931-954

Sameoto D (1981) Horizontal and vertical distributions of zooplankton numbers and biomass off the coast of Perú. Bol Inst Mar Peru Vol Extraord:164-170

Santander H (1981) The zooplankton in an upwelling area off Peru. In: Richards FA (ed) Coastal Upwelling Coastal and Estuarine Sciences 1. Am Geophys Un, Washington DC

Semenova TN, Timonin AG, Flint MV (1982) Horizontal and vertical distribution patterns of mass zooplankton species off Peru. Okeanol 22:297-304
Smith SL, Boyd CM, Lane PVZ (1981a) Short term variation in the vertical distribution of copepods off the coast of northen Peru. Bol Inst Mar Peru Vol Extraord: 112-118

Smith SL, Brink KH, Santander H, Cowles TJ, Huyer A (1981b) The effect of advection on variations in zooplankton at a single location near Cabo Nazca, Perú. In: Richards FA (ed) Coast Estuar Sci $1: 400-410$

Thuesen E, Fernandez MA (1999) Polychaeta. Blackhuys, Leiden

Trevorrow MV (1998) Observations of internal solitary waves near the Oregon coast with an inverted echo sounder. J Geophys Res C Oceans 103:7671-7680

Van Guelpen L, Markle DF, Duggan DJ (1982) An evaluation of accuracy, precision, and speed of several zooplankton subsampling techniques. J Cons Int Explor Mer 40:226-236

Vinogradov (1997) Some problems of vertical distribution of Meso and Macroplankton in the Ocean. Adv Mar Biol 32:2-92

Wing SR, Botsford LW, Ralston SV, Largier JL (1998) Meroplanktonic distribution and circulation in a coastal retention zone of the northern California upwelling system. Limnol Oceanogr 43:1710-1721

Wolter K, Timlin MS (1998) Measuring the strength of ENSO-how does 1997/98 rank? Weather 53:315-324

Wyrtki K (1967) Circulation and water masses in the eastern equatorial Pacific ocean. Int J Oceanol Limnol 1:117-147

Yannicelli B, Castro LR, Valle-Levinson A, Atkinson L, Figueroa D (2006) Vertical distribution of decapod larvae in the entrance of an equatorward facing bay of central Chile: implications for transport. J Plank Res 28:19-37

Zuta S, Guillen O (1970) Oceanografía de las aguas costeras del Peru. Bol Inst Mar Peru 2:161-323 